\title{
THE BRIGHT CHILD.
}

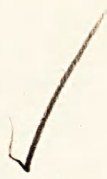

\section{By Ella Frances Lynch,}

Atlantic City, N. J.

As a teacher for many years in the public schools, with an experience ranging from the primary through the grammar and high school grades, I became aroused over the undeniable failure of the public school system to give the children what it professes to guarantee-an education. There seemed so many children classed as "failures," "stupid," or "not up to grade," that, at last, in spite of the overawing splendor of the school system, I dared to wonder if therein lay the difficulty and if these little "failures" did not possess hidden possibilities of greatness, could one but find the right key. On this point I sought the opinion of outsiders,-physicians, parents, business men, and, can best sum up my conclusion in the words of Lodge: "Stupidity and bad teaching are synonymous terms."

The public school system attempts the impossible feat of making a course for all children, irrespective of physical strength, mentality, inheritance, or home environment,-whether they are to be lawyers or blacksmiths, artists or mathematicians.

Plainly this course cannot suit all children. Is it then adapted to the bright child? Dr. Witmer, professor of psychology in the University of Pennsylvania says: "The public schools are not giving the bright child a square deal. He is marking time, waiting for the lame duck to catch up." Is the course intended to fit the dull pupil? Evidently not, in view of the tears shed by the many who, despite all efforts, fail to keep up to grade. It has been suggested that the course is designed for the average pupil. The "average" pupil does not exist. You cannot strike an average between a goose and an eagle nor can you add a dull pupil and a bright pupil together and get anything. A course of study based on this idea is not fitted to anyone. Instead, then, of a school to fit the pupil, the pupil is made to fit the school. The lock-step masquerades under the name of discipline. The rigid curriculum tends with each passing year, to produce more and more the type of factory employees, obliterating individuality and forcing all into the same mould. As Dr. Eliot says,_-"Uniformity is the curse of our schools." 
The public school attempts too much. The rudiments of education are few and these alone should be given the student in his earliest years. Train him in obedience to rightful authority, selfcontrol, self-respect, perseverance, and awaken in him a thirst for knowledge. Thus equipped he is better prepared to make the most of his natural powers and secure an education outside of the public school than under its present curriculum. Minds properly disciplined will in later years grasp with avidity what requires an effort in the earlier years. It is this fruitless effort which creates in the pupil a dislike of the subject. Long ago a good teacher said to his pupils: "There are your books, but if I did nothing more than come here day after day and teach you what is between their covers, I should be very far from doing my duty as a teacher."

The child who spends eight years of five hours a day in acquiring the knowledge demanded for admission to high school, is squandering time. Rightly disciplined, he can grasp in thirty minutes of eager study all that is new and valuable to him in an entire day's assignment.

Much time is wasted for the individual in recitation in the public schools. He can tell you in three minutes what he has learned in geography; yet he must listen for forty minutes to forty other pupils answering questions that will aid the teacher in determining the "mark" to be placed opposite each name in her little book. These marks are important as among other uses they form the basis of the splendid assortment of statistics in the superintendent's office.

Again, more than one subject could well be omitted. Take, for example, American history which has slight claim to be considered a fundamental subject. We find it taught orally in the third and fourth grades, and from a text-book in the fifth and sixth grades. In the seventh grade the weary student greets it as "Not a friend but my most intimate enemy." Then follows eighth grade American history. Nor does a teacher say to some child nauseated because of the repetition of the subject: "John, you seem to understand history fairly well; you may devote this period to other lessons for the rest of the year."

We recognize that the public school attempts to provide a course for all children; that this is no small task; that time and opportunity, equipment and teaching force sufficient to meet the needs of all would mean a tremendous outlay. But it is worth while. The school system too closely resembles the factory system 
where human beings lose all individuality in becoming admirable machines. A few years hence we may see our school work further systematized by "numbering" the pupils.

Our school system will be improved when parents adopt towards it their rightful attitude and demand a course planned by educators,- - parents, physicians, business men, teachers, and theorists. The improvement will consist in a resort to a simpler curriculum in which the pupils shall do a few things well rather than many things poorly. Mastering one thing is better than attempting many things and mastering none. Let the pupil have the sense of victory over one subject and he will attack others with a confidence that assures another conquest. Knowledge is power only when it is the right kind of knowledge and is assimilated and becomes part of the individual. We do not want human machines nor do we want human cyclopedias. The late Dr. Edward Everett Hale said: "At present we are making a great deal too much of points of instruction and of facts. Much more than half the time of our public schools is taken up with statistics."

Desirous of bettering conditions for at least a few children, I established a school of individual instruction, in which the pupils' needs, ability, disposition, health, and other things affecting his educational progress would be taken into account. As I had previously demonstrated the value of such a plan in the schools of northern New York it was an experiment only from the financial standpoint. A few words will make clear the plan of the school; no teacher to have more than six pupils; abundance of light and air; work outdoors when possible,-always with open windows; no home work.

These essentials are taught:

How to study; that "Heaven is not reached at a single bound"; that habits early formed determine character and destiny; that "Genius is an infinite capacity for taking pains"; that "He that ruleth his own spirit is greater than he that taketh a city"; that all work is ennobling, idleness unfruitful, degrading, abhorrent alike to God and man.

Neat and accurate work is demanded but originality is encouraged and, in the realm of mathematics, reward is given for finding a new way to solve a problem.

The first requisite being to teach right habits of study and develop the power of concentration, the beginning seems slow as the seed-time must be. One or two branches only are taken up, one being that in which the pupil is least proficient,-usually arith- 
metic. Owing to the abominable methods of teaching it, there are more failures in this than in any other subject. I have never found a normal child who did not have an aptitude for arithmetic.

Pupils are not arranged in classes. Each is given forty minutes individual attention by his teacher. He returns to the study room and prepares the assigned work, knowing that when it is satisfactorily completed he will be dismissed for the day.

As the weeks go by his capacity for work increases and other subjects are added accordingly. The time spent in school increases, but no pupil remains over four hours a day, and the usual period is two hours.

In this way, surely the natural way, the bright boy is not "marking time" for the dullard; the pupil physically weak will not be pushed to exhaustion and a nervous breakdown, trying to keep pace with the strong. The pupils acquire interest and ambition,-two powerful factors of progress. A boy who in public school proved troublesome, "not up to grade," and failed of promotion, has in a single year become a student and acquired more of real education than three years of public school training gives his companions. He is now prepared to re-enter the public school in an advanced grade and achieve success. 